\title{
Thermal Convection in the North Pacific High Pressure Cell
}

\author{
Kern E. Kenyon \\ 4632 North Lane, Del Mar, USA \\ Correspondence to: Kern E. Kenyon, kernken@aol.com \\ Keywords: North Pacific High, Thermal Convection \\ Received: June 4, 2020 Accepted: July 14, 2020
}

Published: July 17, 2020

Copyright (c) 2020 by author(s) and Scientific Research Publishing Inc. This work is licensed under the Creative Commons Attribution International License (CC BY 4.0). http://creativecommons.org/licenses/by/4.0/

\section{(c) (i) Open Access}

\section{ABSTRACT}

If it is accepted that thermal convection consistently takes place inside the North Pacific High, as proposed here, then the existence of the NPH, as well as its seasonal variation, will be explained simultaneously, building on an earlier attempt. More observations than available at present would help prove that thermal convection happens and pin down its characteristics, since it is not visible. Also the physics of how thermal convection produces relatively high pressure at sea level needs work.

\section{INTRODUCTION}

The idea that thermal convection of some type is taking place most of the time inside the North $\mathrm{Pa}$ cific High Pressure Cell is almost a dead certainty. But at the time that this notion was announced in 1999 [1], the understanding of it was not complete. A better explanation is given here. In particular, the seasonal variation of the NPH is considerably less confusing than it used to be. From the increased understanding comes the estimation that the time-scale for generating the NPH is a month or less. What is left for the future, in the way of gathering available or making new relevant observations, is based on the fact that the thermal convection mechanism itself cannot be seen with the naked eye.

\section{CHRONOLOGY}

In the mid-1940s monthly mean sea level pressure was charted for the whole North Pacific and published [2]. On each chart a pressure value was put down on a diamond grid of alternate five degree latitude/longitude squares, and on several charts contours of constant pressure (isobars) were drawn. In my possession are more than 30 years of these monthly mean sea level pressure maps starting in 1946.

It has been known since then, or perhaps earlier, that the highest sea level pressure occurs over the ocean and most often on the eastern side of the ocean at mid-latitudes. Also in the summer the center of high pressure moves west and the cell swells up essentially covering the whole ocean basin. One consequence is that no storms from the ocean come into North America during the summer. They are shut out 
by the high pressure.

Then in the mid-1970s monthly mean ship-injection temperatures for the North Pacific north of $20 \mathrm{~N}$ were given to me by Jerome Namias. A temperature value occurs for every five degree latitude/longitude square, and I have more than 30 years of these sheets starting in 1947, which unfortunately are still not published. A curious feature on these sheets caught my attention: a large-scale longitudinal maximum in the SSTs off the coast of California. It was present in almost every month along 35 and $40 \mathrm{~N}$ for all years. It did not take very long to notice that the longitudinal SST maximum correlated pretty well with the position of the NPH.

After 10 years of study of all the available data plus new measurements from an extensive hydrographic cruise from California to Japan along $35 \mathrm{~N}$, it was concluded that the longitudinal maximum in the SSTs was the signature of a wide warm surface current flowing northward off California [3]. Wide means $4000 \mathrm{~km}$ at $35 \mathrm{~N}$ and surface means from the surface down to $100 \mathrm{~m}$ at the most. Now the warm water flow is a source of heat for the atmosphere in that region.

Also in the 1970s the SSTs appeared to show that the longitudinal maximum shifted to the west in the summer and returned east in the fall, similar to the seasonal movement of the NPH. At some point it became clear that it was unlikely for the wide warm current to become that much wider in summer, and it did not seem that it could become any faster or deeper either. One of the jobs the northward current does is to convey some of the excess heat from absorbed solar radiation mainly at lower latitudes to higher latitudes in accordance with the heat budget requirement of the ocean. And more heat is absorbed per unit time and area in summer than at other times. At all times some heat needs to be moving north.

Then it was pointed out to me by Joe Reid that in the western tropics of the North Pacific there is a huge surface area where the highest temperatures of the ocean are always found and that these temperatures are no higher in summer than in winter! What happens is that the area of high temperatures increases to the north in the summer. Heat is thereby transported northward in summer by a very much wider surge of warm water than the wide warm current off California does year round [4]. In response the NPH either expands and its center shifts to the west or in some cases a separate high pressure cell is created.

Years later, it was noticed by comparing two figures published in the 1970s that when the longitudinal maxima of SSTs appear to move west in spring and early summer it starts west at $35 \mathrm{~N}$ before it does so at $40 \mathrm{~N}$. A suggestion arising from this observation is that there is a northward component of warm surface water at mid-latitudes in these months. That turns out, by interpretation, to be the very wide northward surge of warm water in summer that impinges from the west, and essentially usually dominates, the wide warm current off California.

\section{CONVECTION EVIDENCE}

One extensive hydrographic cruise was made along $35 \mathrm{~N}$ from California to Japan in March/Aril 1976, and it sliced right through the wide warm current measuring sea surface temperatures continuously and air temperatures every two hours, among many other physical/chemical properties. In the $4000 \mathrm{~km}$ region of the warm current the sea surface was always warmer than the air and by an average of $2 \mathrm{C}$. Thus heat was inferred to be transferred from ocean to atmosphere during that time and at that location [1].

Since the 30 years of SSTs imply that the wide warm current off California is permanent and continuously brings warm water from low to mid-latitudes, it seems probable that the sea surface temperatures under the NPH are always warmer than the air, although the data to verify that are not available.

An exception to the rule would be a situation whereby the NPH is somehow moved east away from the warm current and over land, which generates Santa Anna winds in San Diego. After the connection between the NPH and the warm SSTs has been broken is such a manner, it may take some time (maybe a week or more) to become re-established because winds move faster than ocean currents, which would inhibit the convection heat transfer process between sea and atmosphere. And the heat source itself could be classified as being rather weak, with an average negative air/sea temperature difference of only $2 \mathrm{C}$.

Also from the oceanographic cruise the relative humidity was calculated from the meteorological data 
taken every two hours on the ship's bridge. It was found that the relative humidity was relatively low over the top of the warm flow. This is evidence that comparatively cool dry air was brought down to the sea surface from some altitude, which remains unknown at this time, but provides further evidence for thermal convection [1].

An additional potential piece of evidence in support of thermal convection, which has not been mentioned before now, is that the highest sea level pressures in the whole $35 \mathrm{~N}$ transect occurred at $138 \mathrm{~W}$, which correlates well with the mid-point of the deepest mixed layer depths at $140 \mathrm{~W}$. On the other hand, the highest SSTs were 10 longitude degrees to the west, $150 \mathrm{~W}$. By a previous interpretation the highest temperatures are consistent with the fastest current speeds, whereas a slower current speed in the middle of the flow would tend to favor a greater heat exchange with the atmosphere, leading to higher sea level pressure.

\section{DYNAMICAL POINTS}

To describe the postulated thermal convection generated in the air above the warm current in algebraic quantities is too difficult of a job to carry out at the present time. However, a start can be made.

Suppose a piece of air next to the warm ocean water is heated from below. It will become less dense than the surrounding air and therefore be unstable. It will rise upward, and in fact accelerate upward against gravity. Let the piece of air be large enough and its speed is fast enough that molecular diffusion of heat can be neglected. Consequently by assumption the main physical phenomenon taking place is the transport of heat upward by advection.

A rising column of warm air starts the whole convection going. How the return flow takes place is almost a separate phenomenon, i.e. not a mirror image, except for the constraint imposed by conservation of mass. But that is a very general connection between the two oppositely directed streams, if in fact 'stream' is the right word to use for both up and down motions.

Many configurations exist a priori for the ways that the heat can move up and away from the sea and cooler air return down. It seems unlikely that the small-scale vertical streams of warm air have any rotation about their vertical axes because the imagination does not produce a way that it could happen consistently. The large-scale clockwise rotation of air about the North Pacific High, due to the Coriolis force, probably develops at a later stage after the high pressure at sea level is established.

To narrow down the number of possible arrangements that the convection can take, a principle can be brought in that has appeared recently in connection with a few geophysical features [5]. For example, the hurricane's $100 \mathrm{mph}$ winds and the tornado's $200 \mathrm{mph}$ winds may last as long as they do because the friction in them is essentially zero due to the arrangement of the wind shear. If a fluid has a job to do, like get heat from point $A$ to point $B$, it might in some cases find the easiest way to do it, or the way of least friction. This philosophy is different from the instability theory whereby the most unstable configuration is the one expected to be seen for any length of time. For a given amount of heat, the less friction it encounters, the higher it will be expected to rise.

When a column of heated air ascends, if the speed is a maximum in the center, and falls off linearly outward with increasing radius, then friction will be zero according to the friction term in the Navier-Stokes equations of fluid dynamics. Evaluation of the least friction concept in this context is a possible project for the future.

\section{DISCUSSION}

Mentioned above was the case of an NPH becoming disconnected from the warm current and moving east over land, and if that should happen, it might take a week or more to become re-established. That was a guess based on fact. In the 30 year period of monthly mean sea level pressure maps of the North $\mathrm{Pa}$ cific, several times a double high pressure cell was present in the summer months, one cell in the east as normal and a second one to the west at the same latitude [6]. In each of these special events the secondary western pressure cell sprang up fully developed between two adjacent monthly mean maps, implying a 
generation time-scale of a month or less. Very likely the western pressure cell was generated by thermal convection associated with the second western longitudinal SST maximum, the very wide warm surge which only takes place in summer, but does so every summer.

If one were to look into the index of any one of many contemporary meteorological text books under "convection", he or she would almost always be directed to pages discussing cloud formation, usually including photographs. This only serves to increase the curiosity as to why the present form of thermal convection is not visible.

Among the older literature is a valuable collection, in book form, of 25 journal papers with the title "Theory of Thermal Convection, with Special Application to the Earth's Planetary Atmosphere" [7]. Perhaps in the future a theoretical model in the collection could be modified in an appropriate way in order to be applicable to the type of convection in the NPH envisioned here.

\section{CONCLUSIONS}

The final result of studying the evidence and collecting the reasoning is that the NPH in most months is caused by thermal convection above a permanent wide warm surface current off California. In summer, an additional source of heat for the atmosphere crosses mid-latitudes from the western tropics as a very wide surge of warm surface water. It is proposed that thermal convection over this warm surge is responsible for the westward movement of the NPH's center and expansion of its area.

\section{CONFLICTS OF INTEREST}

The authors declare no conflicts of interest regarding the publication of this paper.

\section{REFERENCES}

1. Kenyon, K.E. (1999) North Pacific High: An Hypothesis. Atmospheric Research, 51, 15-34. https://doi.org/10.1016/S0169-8095(98)00110-0

2. Fofonoff, N.P. (1960) Transport Computations for the North Pacific, 1955. Fisheries Research Report of Canada, Manuscript Report Series, No. 77.

3. Kenyon, K.E. (1981) A Shallow Northeastward Current in the North Pacific. Journal of Geophysical Research, 83, 6115-6122. https://doi.org/10.1029/JC083iC12p06115

4. Kenyon, K.E. (2015) Non-Seasonal SSTs of the Western Tropical Pacific. Natural Science, 7, 605-612. https://doi.org/10.4236/ns.2015.713060

5. Kenyon, K.E. (2019) Bernoulli Loops with No Friction. European International Journal of Science and Technology, 8, No. 10. https://doi.org/10.4236/ns.2019.1110030

6. Kenyon, K.E. (2016) Double North Pacific High in Summer. Natural Science, 8, No. 5.

7. Saltzman, B., Ed. (1962) Theory of Thermal Convection. Dover Publications, New York. 